University of Miami Law School University of Miami School of Law Institutional Repository

2018

\title{
Evolution of the Arbitration Forum as a Response to Mandatory Arbitration
}

Teresa J. Verges

University of Miami School of Law, tverges@law.miami.edu

Follow this and additional works at: https://repository.law.miami.edu/fac_articles

Part of the Dispute Resolution and Arbitration Commons

\section{Recommended Citation}

Teresa J. Verges, Evolution of the Arbitration Forum as a Response to Mandatory Arbitration, 18 Nev. L.J. 437 (2018).

This Article is brought to you for free and open access by the Faculty and Deans at University of Miami School of Law Institutional Repository. It has been accepted for inclusion in Articles by an authorized administrator of University of Miami School of Law Institutional Repository. For more information, please contact library@law.miami.edu. 


\section{HEINONLINE}

Citation:

Teresa J. Verges, Evolution of the Arbitration Forum as

a Response to Mandatory Arbitration, $18 \mathrm{Nev}$. L.J. 437

(2018)

Content downloaded/printed from $\underline{\text { HeinOnline }}$

Fri Jun 22 11:45:19 2018

-- Your use of this HeinOnline PDF indicates your acceptance of HeinOnline's Terms and Conditions of the license agreement available at https://heinonline.org/HOL/License

-- The search text of this PDF is generated from uncorrected OCR text.

-- To obtain permission to use this article beyond the scope of your HeinOnline license, please use:

\section{Copyright Information}

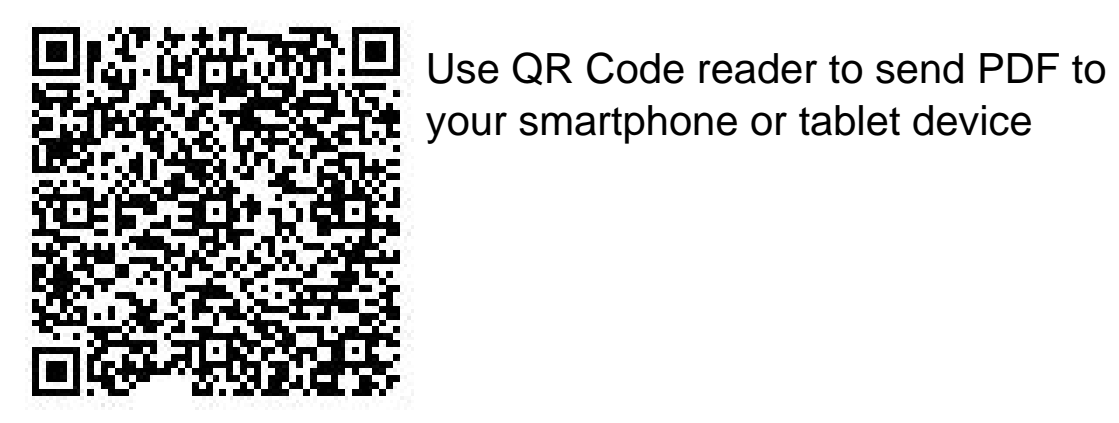




\title{
EVOLUTION OF THE ARBITRATION FORUM AS A RESPONSE TO MANDATORY ARBITRATION
}

\author{
Teresa J. Verges*
}

INTRODUCTION

Buoyed by decades of U.S. Supreme Court decisions elevating the Federal Arbitration Act ("FAA") ${ }^{1}$ to "super-contract" status, ${ }^{2}$ the use of pre-dispute arbitration agreements ("PDAAs") in the United States has become ubiquitous. Historically, arbitration was a dispute resolution option negotiated by two or more parties to resolve purely private, contractual disputes. ${ }^{3}$ Today, mandatory arbitration has expanded to myriad sectors, including all manners of consumer and service disputes, investor disputes, employment and civil rights disputes. "From birth to death, the use of arbitration has crept into nearly every corner of Americans' lives, encompassing moments like having a baby, going to school, getting a job, buying a car, building a house and placing a parent in a nursing home." 4

In these non-traditional contexts, PDAAs are not negotiated and knowing consent to arbitration rarely exists. ${ }^{5}$ While a customer's signature on a multiple-

* Teresa Verges is the Director of the University of Miami School of Law Investor Rights Clinic and a Lecturer in Law. The author would like to thank Benjamin P. Edwards for his suggestions and comments. I am also grateful for the research assistance of Samantha Nugent, UM Law JD candidate, 2018.

19 U.S.C. $\$ \S 1-307$ (2012) (originally enacted as the United States Arbitration Act of Feb. 12,1925 , ch. 213,43 Stat. 883 ).

${ }^{2}$ Jill I. Gross, The Historical Basis of Securities Arbitration as an Investor Protection Mechanism, 2016 J. DisP. RESOL. 171, 180 (2016).

${ }^{3}$ Imre Stephen Szalai, Exploring the Federal Arbitration Act Through the Lens of History, 2016 J. DISP. RESOL. 115, 118 (2016).

${ }^{4}$ Jessica Silver-Greenberg \& Michael Corkery, In Arbitration, a 'Privatization of the Justice System,' N.Y. Times, Nov. 1, 2015, at A1 (this article was one of a front page, three-part series in The New York Times that focused on the ubiquity of mandatory arbitration clauses) See also Michael Corkery \& Jessica Silver-Greenberg, In Retigious Arbitration, Scripture Is the Rule of Law, N.Y. Times, Nov. 2, 2015, at A1; Jessica Silver-Greenberg \& Robert Gebeloff, Arbitration Everywhere, Stacking the Deck of Justice, N.Y. TiMES, Oct. 31, 2015, at A1.

5 Consumer Fin. Prot. Bureau, Arbitration Study, Rfport to Congress, Pursuant to

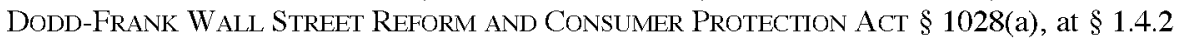
(2015) ("CFPB Arbitration Study"). Most retail investors, for example, are unaware of mandatory PDAAs in their customer agreements with their financial advisor, and are often 
paged account agreement, or "click" on the "I Agree" tab at the end of a list of "Terms and Conditions" on an internet agreement, may legally constitute "consent," few consumers knowingly agree to waiving their right to judicial access and all the protections afforded by a judicial forum. Moreover, the increasing use of class-action waivers in consumer and employment agreements forces more disputes into arbitral forums, while effectively precluding claims that are too small to justify the litigation costs from ever being brought.

This trend requires us to reexamine whether the arbitral forum can (and should) evolve to accommodate a growing number of forced participants with claims involving non-traditional areas that implicate, at least in part, matters of public policy. In an article appearing in this issue, Professor Deborah Hensler and Damira Khatam, J.S.D., correctly observe that the expanding application of arbitration to encompass disputes that implicate matters of public policy have increasingly pushed private forums across domestic arbitration, international commercial arbitration, and investor-state arbitration procedure to incorporate certain due process protections and other procedures that resemble those found in judicial forums. ${ }^{7}$ They argue that this re-invention of arbitration undermines both the value of arbitration for purely private disputes (presumably among tru1y consenting participants to that process), as well as undermining courts and the value of judicial resolution of societal issues. ${ }^{8}$

Certainly in the context of domestic arbitration (with which I am most familiar), I could not agree more that we need to re-examine the scope of arbitration, particularly when widespread use of PDAAs and class-action waivers sweeps into arbitration millions of potential claims that implicate matters of public policy. Moreover, a historical examination of domestic arbitration and the purpose of the FAA reveal that current Supreme Court jurisprudence on

shocked to learn that they must bring their claims in arbitration. See N. Am. Sec. Adm'rs Ass'n, Written Statement of the North American Securities Administrators Association (NASAA) on "Mandatory Binding Arbitration: Is it Fair and Voluntary?," at 2, http://www.nasaa.org/wp-content/uploads/2011/07/NASAA-Arbitration-Statement-

9.15.09.pdf. [https://perma.cc/5K2E-832W] (Sept. 15, 2009) ("Many investors remain unaware of this industry arbitration provision, fail to appreciate its significance, or are powerless to negotiate a different approach to dispute resolution with their brokers.").

${ }^{6}$ See, e.g., AT\&T Mobility LLC v. Concepcion, 563 U.S 333, 336-39 (2011) (boilerplate language in telephone service contract); Dean Witter Reynolds, Inc. v. Byrd, 470 U.S. 213, 215 (1985) (language in agreement opening brokerage account); Sgouros v. TransUnion Corp., 817 F.3d 1029, 1036 (7th Cir. 2016) (clicking "I accept" on website agreement can bind customer to arbitration provided that the button was near the service agreement or access to the service agreement); Hancock v. Am. Tel. \& Tel. Co., 701 F.3d 1248, 1256-58 (10th Cir. 2012) (clicking "I agree" to an agreement that user has the opportunity to read on the website constitutes consent).

${ }^{7}$ Deborah R. Hensler \& Damira Khatam, Re-Inventing Arbitration: How Expanding the Scope of Arbitration Is Re-Shaping Its Form and Blurring the Line Between Private and Public Adjudication, 18 Nev. L. J. 381, 381 (2018).

${ }^{8}$ Id. 
federal arbitration has strayed well beyond the FAA's purpose and scope. ${ }^{9}$ Given the current composition of the Court, only legislation can realign domestic arbitration practice with its historical purpose. However, as discussed below, legislation has largely stalled and limited regulatory actions to protect consumers face strong political headwinds. ${ }^{10}$

A concurrent approach is to continue pushing for evolution of the arbitral forum to accommodate the increasing number of forced participants with claims that implicate matters of public policy, including federal statutory claims. Perhaps the best example of such evolution is in the context of securities arbitration in the forum administered by the Financial Industry Regulatory Authority ("FINRA"). ${ }^{11}$ Pushed by the Securities and Exchange Commission ("SEC") and investor advocates, FINRA has made significant changes to its arbitration rules governing customer disputes to better serve investors. Although concerns remain about investor access, the lack of transparency, and investors' perception of fairness, among other things, FINRA arbitration compares favorably to arbitration of consumer claims. ${ }^{12}$

Similarly, incorporating due process and procedural reforms to increase access, fairness, and transparency in other arbitration forums provides increased protections for individuals forced into a process that many feel is rigged against them. ${ }^{13}$ It may also provide a less-expensive alternative to litigation of smaller claims in some contexts, such as small-investor claims against their brokers. ${ }^{14}$ To the extent such reforms incorporate procedures common in judicial litigation, and added costs, businesses may re-think their use of mandatory PDAAs in the first place.

\footnotetext{
${ }^{9}$ See Ronald G. Aronovsky, The Supreme Court and the Future of Arbitration: Towards a Preemptive Federal Arbitration Procedural Paradigm?, 42 Sw. L. REv. 131, 174-75 (2012) (the Court's arbitration jurisprudence "has created a robust, preemptive federal proarbitration policy ... largely untethered to the language of the FAA").

${ }^{10}$ See infra notes 43-66 and accompanying discussion.

${ }^{11}$ FINRA is a private, not-for-profit corporation functioning as a self-regulatory organization registered with the Securities and Exchange Commission. FINRA was formed in July 2007 by the consolidation of the National Association of Securities Dealers ("NASD") and the regulatory arm of the New York Stock Exchange ("NYSE"). FINRA is responsible for regulatory oversight of broker-dealers in the U.S. Securities and Exchange Act of 1934 "Exchange Act" $\$ 15(\mathrm{~b})(8), 15$ U.S.C. $\$ 78 o(\mathrm{~b})(8)$; see also Karsner v. Lothian, 532 F.3d 876, 880 (D.C. Cir. 2008) ("FINRA, as NASD's successor, is 'the only officially registered 'national securities association' under [the Exchange Act]." ') (citing Nat'1 Ass'n of Sec. Dealers, Inc. v. SEC, 431 F.3d 803, 804 (D.C. Cir. 2005)). All broker dealers must be registered with FINRA. Exchange Act $\S 15(\mathrm{~b})(8)$, 15 U.S.C. $\S 78 o(\mathrm{~b})(8)$; Fiero v. Fin. Indus. Regulatory Auth., Inc., 660 F.3d 569, 571 (2d Cir. 2011).

12 See infra notes 66-99 and accompanying discussion.

${ }^{13}$ Thomas J. Stipanowich, The Arbitration Fairness Index: Using a Public Rating System to Skirt the Legal Logjam and Promote Fairer and More Effective Arbitration of Employment and Consumer Disputes, 60 KAN. L. REV. 985, 1028 (2012).

${ }^{14}$ Jill I. Gross, AT\&T Mobility and the Future of Small Claims Arbitration, 42 Sw. L. REv. 47,65 (2012).
} 


\section{THE EXPANDING SCOPE OF MANDATORY ARBITRATION}

\section{A. Widespread Use of PDAAs in Non-Traditional Contexts}

Mandatory arbitration provisions have long been used to resolve purely private, contractual disputes between merchants and commercial businesses. ${ }^{15}$ PDAAs allow businesses to manage litigation costs and risks by providing certainty of the forum and the rules applicable to the resolution of their disputes, privacy, a faster and less costly process, and finality of the decision, which is often made by an arbitration panel composed of industry experts. ${ }^{16}$ In response to initial judicial hostility to arbitration, Congress passed the FAA in 1925, which declared PDAAs valid, irrevocable, and enforceable. ${ }^{17}$

The Supreme Court has held that the purpose of the FAA was to place arbitration agreements on "the same footing as other contracts." ${ }^{18}$ Notwithstanding this principle re-iterated by the Court in a long line of cases through AT\&T Mobility LLC v. Concepcion ${ }^{19}$ and American Express Co.v. Italian Colors Restaurants ${ }^{20}$ Supreme Court jurisprudence in the last forty years has actually thwarted that purpose, establishing, instead, a judicial policy favoring arbitration. ${ }^{21}$ The Supreme Court has held that the FAA creates a federal substantive law of

15 Jeff Sovern et al., "Whimsy Little Contracts" with Unexpected Consequences: An Empirical Analysis of Consumer Understanding of Arbitration Agreements, 75 MD. L. REv. 1, 5-6 (2015); see also Szalai, supra note 3 , at 117,

The history of the FAA's enactment helps demonstrate that the FAA was originally intended to provide a framework for federal courts to support a limited, modest system of private dispute resolution for commercial disputes, not the expansive system that exists today involving both state and federal courts and covering virtually all types of non-criminal disputes.

${ }^{16}$ Myriam Gilles, The Day Doctrine Died: Private Arbitration and the End of Law, $2016 \mathrm{U}$. ILL. L. REV. 371, 372, 390 (2016).

${ }^{17}$ Gilmer v. Interstate/Johnson Lane Corp., 500 U.S. 20, 24-25 (1991). Section 2 of the FAA provides that:

A written provision in any maritime transaction or a contract evidencing a transaction involving commerce to settle by arbitration a controversy thereafter arising out of such contract or transaction, or the refusal to perform the whole or any part thereof, or an agreement in writing to submit to arbitration an existing controversy arising out of such a contract, transaction, or refusal, shall be valid, irrevocable, and enforceable, save upon such grounds as exist at law or in equity for the revocation of any contract.

9 U.S.C. $\$ 2$ (1947).

${ }^{18}$ Dean Witter Reynolds, Inc. v. Byrd, 470 U.S. 213, 219 (1985) (citing H.R. REP. No. 96, 68th Cong., 1st Sess., 1 (1924)); see also AT\&T Mobility, LLC v. Concepcion, 563 U.S. 333,339 (2011) ("In line with these principles, courts must place arbitration agreements on an equal footing with other contracts ... and enforce them according to their terms").

${ }^{19}$ Concepcion, 563 U.S. at 339.

${ }^{20}$ Am. Express Co. v. Italian Colors Restaurant, 133 S. Ct. 2304, 2309 (2013).

${ }^{21}$ See Jodi Wilson, How the Supreme Court Thwarted the Purpose of the Federal Arbitration Act, 63 CASE W. RES. L. REv. 91, 94 (2012). See also Aronovsky, supra note 9 at 134 (the Court's expansive " "pro-arbitration policy' may be leading toward a preemptive federal arbitration procedural paradigm"). 
arbitration applicable in both federal and state courts, which preempts conflicting state law. ${ }^{22}$

Businesses' use of PDAAs greatly expanded as the Supreme Court's arbitration jurisprudence elevated the FAA. The Supreme Court upheld mandatory arbitration of investor disputes with their brokers, ${ }^{23}$ consumer contracts, ${ }^{24} \mathrm{em}$ ployment agreements, ${ }^{25}$ and nursing home admission applications, ${ }^{26}$ among others, providing the groundwork for enforcement of virtually every type of arbitration agreement in any context. ${ }^{27}$ In contrast to PDAAs used in private, commercial contracts between businesses, PDAAs in consumer contracts or in other non-traditional contexts are not negotiated, and individuals subject to them rarely know that they exist or deprive them of their right to pursue judicial remedies. ${ }^{28}$

Businesses have further sought to limit litigation costs of class actions by including class-action waivers in their contracts. ${ }^{29}$ These provisions generally prohibit individuals from bringing a judicial class-action or other collective action (such as in the arbitral forum itself) or both. ${ }^{30}$ As part of a mandatory PDAA, a class-action waiver requires an aggrieved party to bring his or her claim - regardless of its size-individually in arbitration. ${ }^{31}$ Rejecting arguments

22 Southland Corp. v. Keating, 465 U.S. 1, 10, 16 (1984).

23 Shearson/Am. Express, Inc. v. McMahon, 482 U.S. 220, 222, 238 (1987).

${ }^{24}$ Concepcion, 563 U.S. at 352 (contract with telephone carrier services); CompuCredit Corp. v. Greenwood, 565 U.S. 95, 97, 104-05 (2012) (credit card agreements).

${ }^{25}$ Circuit City Stores v. Adams, 532 U.S. 105, 123 (2001). See also Jean R. Sternlight, Disarming Employees: How American Employers Are Using Mandatory Arbitration to Deprive Workers of Legal Protection, 80 BROOK. L. REV. 1309, 1317-19 (2015) (noting that 20 percent of non-unionized employees are covered by arbitration clauses, and that this number will grow as recent Supreme Court cases on class-action waivers will likely encourage more employers to use them).

${ }^{26}$ Marmet Health Care Ctr., Inc. v. Brown, 565 U.S. 530, 533-34 (2012) (per curiam). Most recently the Supreme Court overturned a Kentucky Supreme Court decision which held that a power of attorney must expressly confer authority to waive the right to a jury trial in order be able to sign a PDAA; the Court held the Kentucky Supreme Court rule "single[d] out arbitration agreements for disfavored treatment." Kindred Nursing Ctrs. Ltd. P'ship v. Clark, 137 S. Ct. 1421, 1425 (2017).

${ }^{27}$ Michael J. Yelnosky, DIRECTV, Inc. v. Imburgia and the Continued Ascendance of Federal Common Law: Class-Action Waivers and Mandatory Arbitration Under the Federal Arbitration Act, 22 ROGER WILLIAMS U. L. REV. 287, 287 (2017).

${ }^{28}$ Sovern et al., supra note 15 at 58-61 (in an empirical study of consumers' awareness of the existence and effect of arbitration provisions in their consumer contracts, less than 9 percent of consumers that reviewed a standard credit card agreement with a PDAA realized that the contract had both an arbitration provision and that it would prevent them from bringing a claim in court).

${ }^{29}$ Richard Frankel, "What We Lose in Sales, We Make Up in Volume": The Faulty Logic of the Financial Services Industry's Response to the Consumer Financial Protection Bureau's Proposed Rule Prohibiting Class Action Bans in Arbitration Clauses, 48 ST. MARY's L.J. 283, 285-86 (2016).

${ }^{30} I d$. at 285 .

31 AT\&T Mobility LLC v. Concepcion, 563 U.S. 333, 351-52 (2011). 
that such class-action waivers effectively deprive consumers with small claims from pursuing their rights, the Court held in Concepcion that the FAA compels enforcement of arbitration agreements according to their terms, and preempts contrary state law that classifies class-action waivers in consumer contracts as unconscionable. $^{32}$

Any hopes that the "effective vindication" doctrine ${ }^{33}$ would serve to protect access to courts based on the size of the individual claim were dashed in Italian Colors where Justice Scalia, writing for the majority, dismissed the doctrine as mere dicta and rejected the notion that the costs of pursuing individualized claims in arbitration could invalidate a PDAA. ${ }^{34}$ Reasoning that the doctrine originated from a desire to protect the prospective assertion of rights, ${ }^{35}$ the Court made clear that the doctrine does not invalidate a mandatory PDAA due to costs associated with proving the claim. ${ }^{36}$ "[T]he fact that it is not worth the expense involved in proving a statutory remedy does not constitute the elimination of the right to pursue that remedy." 37 Concepcion and Italian Colors are widely regarded as having dealt a fatal blow to judicial class actions brought on behalf of consumers, civil rights plaintiffs, and others. ${ }^{38}$

${ }^{32} I d$. at $338-39$.

33 The "effective vindication" doctrine was derived from language in Mitsubishi Motors Corp. v. Soler Chrysler-Plymouth, Inc., where the Supreme Court, in compelling arbitration of antitrust and unfair competition claims, stated that "so long as the prospective litigant effectively may vindicate its statutory cause of action in the arbitral forum, the statute [providing the cause of action] will continue to serve both its remedial and deterrent function." 473 U.S. 614,637 (1985).

34 American Express v. Italian Colors Restaurant, 133 S. Ct. 2304, 2311 (2013).

35 According to the majority, examples of such barriers to the potential assertion of statutory rights include an arbitration provision forbidding the assertion of certain rights of action in the first place, or an arbitral system that imposes "administrative fees" that are "so high as to make access to the forum impracticable." Id. at 2310-11.

${ }^{36} I d$. at 2311.

${ }^{37}$ Id.

38 See generally Sarah Rudolph Cole, On Babies and Bathwater: The Arbitration Fairness Act and the Supreme Court's Recent Arbitration Jurisprudence, 48 Hous. L. REV. 457, 46264 (2011) ("[T]he most pressing issue in consumer arbitration, in the wake of recent Supreme Court decisions, is the lack of a viable forum for consumers with low value claims."); Miriam Gilles \& Gary Friedman, After Class: Aggregate Litigation in the Wake of AT\&T Mobility v. Concepcion, 79 U. CHI. L. REV. 623, 627 (2012) (Concepcion all but forecloses aggregate litigation for consumers, civil rights plaintiffs, and others because companies can essentially insulate themselves with waiver provisions that will be upheld); Gross, supra note 14, at 49 ("By inserting a class action waiver clause in their consumer contracts, companies can prevent consumers from aggregating small claims, forcing them to pursue small claims individually.") (citations omitted); Jean R. Sternlight, Tsunami: AT\&T Mobility LLC v. Concepcion Impedes Access to Justice, 90 OR. L. REV. 703, 704 (2012) ("It is highly ironic but no less distressing that a case with a name meaning 'conception' should come to signify death for the legal claims of many potential plaintiffs.") (emphasis added). 


\section{B. Legislative Re-Alignment of Domestic Arbitration Stalled}

Consumer and investor protection advocates have pushed for legislation to address the due process and public policy concerns raised by the widening scope of mandatory arbitration into these non-traditional areas. In 2017 alone, Democratic members of Congress have introduced (or re-introduced) no less than ten bills in the new Congress to limit or ban the use of PDAAs or classaction waivers, or otherwise provide greater transparency and consumer protections in various contexts. ${ }^{39}$ The most expansive, the Arbitration Fairness Act, would amend the FAA to ban mandatory arbitration of consumer (defined to include investor), employment, antitrust, and civil rights disputes. ${ }^{40} \mathrm{~A}$ version of the Arbitration Fairness Act has been introduced in every Congress since 2007.41

Other proposed legislation is more narrowly tailored to prohibit the use of PDAAs or class-action waivers in specific contexts. Four bills have been introduced that do not amend the FAA, but rather, amend other federal statutes to address mandatory arbitration in agreements between investors and their brokers or investment advisers, ${ }^{42}$ consumer bank and credit card agreements ${ }_{,}^{43}$ student enrollment agreements at colleges and universities, ${ }^{44}$ and employment agreements. $^{45}$

Still other bills seek to address the lack of transparency in private arbitration and the implications of that process on matters of public policy. The Arbi-

\footnotetext{
39 See Mandatory Arbitration Transparency Act of 2017, S. 647, 115th Cong. (2017); Arbitration Fairness Act of 2017, H.R. 1374, 115th Cong. (2017); Safety Over Arbitration Act of 2017, S. 542, 115th Cong. (2017); Arbitration Fairness Act of 2017, S. 537, 115th Cong. (2017); Arbitration Transparency Act of 2017, H.R. 832, 115th Cong. (2017); Court Legal Access and Student Support (CLASS) Act of 2017, S. 553, 115th Cong. (2017); Court Legal Access and Student Support (CLASS) Act of 2017, H.R. 2301, 115th Cong. (2017); Justice for Servicemembers Act of 2017, H.R. 2631, 115th Cong. (2017); Investor Choice Act of 2017, H.R. 585, 115th Cong. (2017); Justice for Victims of Fraud Act of 2017, H.R. 1414, 115th Cong. (2017).

${ }^{40}$ Arbitration Fairness Act of 2017, H.R. 1374, 115th Cong. (2017); Arbitration Fairness Act of 2017, S. 537, 115th Cong. (2017).

${ }^{41}$ Arbitration Fairness Act of 2007, S. 1782, 110th Cong. (2007); Arbitration Fairness Act of 2007, H.R. 3010, 110th Cong. (2007).

42 Investor Choice Act of 2017, H.R. 585, 115 th Cong. \$\$ 3-4 (2017) (amends the Securities Exchange Act of 1934 and the Investment Advisers Act of 1940 to prohibit mandatory PDAAs).

43 Justice for Victims of Fraud Act of 2017, S. 552, 115th Cong. (2017) (amends the Truth in Lending Act and the Electronic Fund Transfer Act); Justice for Victims of Fraud Act of 2017, H.R. 1414, 115th Cong. (2017).

${ }^{44}$ Court Legal Access and Student Support (CLASS) Act of 2017, S. 553, 115th Cong. (2017) (amends the Higher Education Act of 1965 to prohibit mandatory arbitration clauses). ${ }^{45}$ Protecting America's Workers Act of 2017, H.R. 914, 115th Cong. (2017) (amends the Occupational and Safety Health Act of 1970 to prohibit the use of PDAAs in connection with employee whistleblower complaints); Justice for Servicemembers and Veterans Act of 2017, S. 646, 115th Cong. (2017) (bans mandatory arbitration in employment rights of veterans and service members).
} 
tration Transparency Act of 2017, for example, would amend the FAA to provide for public arbitration hearings of consumer disputes involving consumer products or services. ${ }^{46}$ Other legislative proposals would amend the FAA to prohibit the enforcement of mandatory PDAAs in disputes that implicate matters of public health or safety, ${ }^{47}$ or in the context of an employment or consumer agreement that would prohibit whistleblower or other reporting of unlawful conduct. ${ }^{48}$ Finally, the Restoring Statutory Rights Act of 2017 would amend the FAA to restore its application to purely private, contractual disputes, by prohibiting PDAAs in cases involving the interpretation of a federal or state statute, or the U.S. Constitution, or a state's constitution. ${ }^{49}$

Given Congress's current composition, it is highly unlikely that any of the proposed legislation amending the FAA will pass. While legislation amending other federal statutes to provide carve outs for specific types of disputes could fare better because they focus on specific areas, they also face difficult odds.

\section{Regulatory (In)Action and Policy Shifts}

Regulatory review of the use and impact of PDAAs and class-action waivers arguably provides a path to meaningful reform. Although limited in scope to the particular arena, agency rules are issued after months (or years) of study, a public notice-and-comment process, and other procedures under the Administrative Procedure Act ("APA") ${ }^{50}$ As such, a rule promulgated under the APAincluding a rule limiting mandatory arbitration in a particular context-is usually substantiated with compelling public policy arguments and data in support of the rule, thereby providing a presumption of validity. ${ }^{51}$ Yet recent events have shown that regulatory reform is also at the mercy of political forces, as the Trump administration has swiftly moved to halt, revise, or overturn regulations in every arena, including those curbing mandatory arbitration.

Under the Dodd-Frank Wall Street Reform and Consumer Protection Act of 2010 ("Dodd-Frank"), ${ }^{52}$ Congress expressly authorized the newly-created Consumer Fraud Protection Bureau ("CFPB") to conduct a study on the use of mandatory arbitration provisions in banking, credit card and other lending agreements, and to prohibit or limit the use of mandatory arbitration provi-

${ }^{46}$ Arbitration Transparency Act of 2017, H.R. 832, 115th Cong. (2017).

47 Safety Over Arbitration Act of 2017, S. 542, 115th Cong. (2017).

${ }^{48}$ Mandatory Arbitration Transparency Act of 2017, S. 647, 115th Cong. (2017).

${ }^{49}$ Restoring Statutory Rights and Interests of the States Act of 2017, S. 550, 115th Cong. (2017); Restoring Statutory Rights and Interests of the States Act of 2017, H.R. 1396, 115th Cong. (2017)

${ }^{50} 5$ U.S.C. $\S \S 552-553(2017)$.

${ }^{51}$ Chevron, U.S.A., Inc. v. Nat. Res. Def. Council, Inc., 467 U.S. 837, 844 (1984) ("We have long recognized that considerable weight should be accorded to an executive department's construction of a statutory scheme it is entrusted to administer, and the principle of deference to administrative interpretations.")

${ }^{52}$ Dodd-Frank Wall Street Reform and Consumer Protection Act, Pub. L. No. 111-203, H.R. 4173 , 111 th Cong. (2010). 
sions. ${ }^{53}$ After years of study and public field hearings, ${ }^{54}$ on May 5, 2016 the CFPB released for public comment a proposed rule that would bar banks, lenders, and other providers of certain financial products from using mandatory arbitration provisions that include class-action waivers. ${ }^{55}$ The CFPB received over 110,000 comment letters on its proposal and, on July 19, 2017, published a final rule that bans the use of class-action waivers in consumer contracts with providers of banking, credit, and lending. ${ }^{56}$ The proposed rule also increases transparency by requiring companies that use arbitration to provide the CFPB with the pleadings and awards rendered in those proceedings. ${ }^{57}$ The new rule will not likely go into effect, however, because Congress exercised its authority to reverse the rule under the Congressional Review Act, ${ }^{58}$ and President Trump is expected to sign the legislation. ${ }^{59}$

Agency rules that have been issued are also at peril. For example, the Department of Health and Human Services Centers for Medicare \& Medicaid Services ("CMS") issued a final rule on October 4, 2016 titled, "Reform of Requirements for Long-Term Care Facilities," that would have barred nursing homes receiving federal Medicare or Medicaid funds from using PDAAs with

${ }^{53} I d . \S 1028$ (codified at 12 U.S.C. $\$ 5518(2010)$ ). The Dodd-Frank Act also authorized the SEC to restrict the use of mandatory arbitration provisions. Id. $\$ 921,124$ Stat. 1841 (2010) (codified at 15 U.S.C. $\$ 78 \circ(0)(2010)$ ). However, the SEC has not yet acted on this authority. Pursuant to section 913 of the Dodd-Frank Act, the SEC conducted a study to evaluate the legal and regulatory standards for the protection of investors that, among other things, included a review of pre-dispute arbitration agreements. Although the staff conducted the study and discussed the growing use of PDAAs, it did not offer any recommendations for change. See U.S. SEC. \& ExCH. COMM'N, STUdy on INVESTMENT Advisers AND BROKERDEALERS, at 80-82, 133-35 (2011).

${ }^{54}$ The CFPB launched its study in April 2012 and published its findings three years later in a 728-page report to Congress. Consumer Fin. Prot. BurEau, Arbitration Study: REPort to Congress PuRsuant to DodD-Frank Wall StreEt REForm and CONSUMER PROTECTION ACT $\$ 1028$ (a) (March 2015).

55 Arbitration Agreements, 81 Fed. Reg. 32830 (proposed May 24, 2016) (to be codified at 12 C.F.R. pt. 1040).

${ }^{56}$ Agreements, 82 Fed. Reg. 33210 (July 19, 2017) (to be codified at 12 C.F.R. 1040); see also Consumer Fin. Prot. Bureau, CFPB Issues Rule to Ban Companies From Using Arbitration Clauses to Deny Groups of People Their Day in Court (July 10, 2017), https:/Www.consumerfinance.gov/about-us/newsroom/cfpb-issues-rule-ban-companies-

using-arbitration-clauses-deny-groups-people-their-day-court $\quad[\mathrm{https} / /$ perma.cc/4UN6VTMJ].

57 Arbitration Agreements, 82 Fed. Reg. 33210 (Jul. 19, 2017) (to be codified at 12 C.F.R. pt. 1040).

${ }_{58}$ The Congressional Review Act, 5 U.S.C. $\$ \S 801-808$ (1996), gives Congress the authority to pass a joint resolution to reverse an agency rule within sixty legislative days of its publication in the federal register. If both houses pass joint resolutions of disapproval and the President signs the resolution, the regulation is nullified, and provisions that had already been effective are retroactively negated. Moreover, a new rule in "substantially the same form" as the rejected rule may not be issued unless specifically authorized by Congress.

${ }_{59}$ Reuters, Republicans, Wall Street Score Victory in Dismantling Class-Action Rule, N.Y. TIMEs (Oct. 25, 2017), https:/www.nytimes.com/reuters/2017/10/25/business/25reuters-usaconsumers-arbitration.html [https://perma.cc/WMA7-ARCD]. 
their residents or their representatives.$^{60}$ Several nursing homes and the American Health Care Association challenged the new regulation prior to its taking effect in November 2016, seeking an injunction to prevent enforcement of the rule on the grounds that the CMS exceeded its authority and that the regulation violated the FAA. ${ }^{61}$ The district court granted an injunction and, on January 5, 2017, the CMS appealed to the United States Court of Appeals for the Fifth Circuit. ${ }^{62}$ However, the CMS withdrew its appeal before its brief was due in June 2017, and has since issued a proposed rule to remove the prohibition on PDAAs, which instead require enhanced notice provisions for residents and their families. ${ }^{63}$

Similarly, the Department of Education ("DOE") published final regulations in November 2016 that, among other things, prohibited the use of PDAAs and class-action waivers in college student loan agreements. ${ }^{64}$ In May 2017, the California Association of Private Postsecondary Schools filed a complaint challenging the regulations and seeking injunctive relief. ${ }^{65}$ Two weeks before the new DOE regulations were to take effect, the DOE published a new rule postponing the implementation of "certain provisions" of the final regulationsincluding the provisions prohibiting PDAAs and class-action waivers - "until the judicial challenges to the final regulations [were] resolved." ${ }^{66}$ Even if the DOE argues in favor of some parts of the 2016 final rules, however, it will likely reverse course on (or not defend) the prohibition against PDAAs and class-

${ }^{60}$ Medicare and Medicaid Programs; Reform of Requirements for Long-Term Care Facilities, 81 Fed. Reg. 68688,68690 (Oct. 4, 2016) (to be codified at 42 C.F.R. pts. 405, 431, $447,482,483,485,488$, and 489$)$.

${ }^{61}$ See Am. Health Care Ass'n. v. Burwell, 217 F. Supp. 3 d 921, 925 (N.D. Miss. 2016).

${ }^{62}$ Notice of Appeal, Am. Health Care Ass'n v. Burwell, No. 16-00233 (N.D. Miss. Jan. 5, 2017).

63 Medicare and Medicaid Programs; Revision of Requirements for Long-Term Care Facilities: Arbitration Agreements, 82 Fed. Reg. 26649 (proposed June 8, 2017) (to be codified at 42 C.F.R. pt. 483). The CMS reviewed the prior 2016 rule pursuant to the Trump administration's January 30, 2017 Executive Order, "Reducing Regulation and Controlling Regulatory Costs." Id. at 26650; see Exec. Order No. 13771, 82 Fed. Reg. 9339 (Feb. 3, 2017). The proposed rule would retain the requirements of the 2016 rule that nursing homes choosing to use PDAAs explain to residents their terms in plain language (in the language the resident or representative understands) and post notice of its use in its facilities. Id. at 26651.

${ }^{64}$ Student Assistance General Provisions, Federal Perkins Loan Program, Federal Family Education Loan Program, William D. Ford Federal Direct Loan Program, and Teacher Education Assistance for College and Higher Education Grant Program, 81 Fed. Reg. 75926, 76087-88 (Nov. 1, 2016) (to be codified at 34 C.F.R. pts. 30, 668, 674, 682, 685 and 686).

${ }^{65}$ Complaint \& Prayer for Declaratory \& Injunctive Relief at 2, Cal. Ass'n Private Postsecondary Schs. v. DeVos, No. 17-CV-00999 (D.D.C. May 24, 2017).

${ }^{66}$ Student Assistance General Provisions, Federal Perkins Loan Program, Federal Family Education Loan Program, William D. Ford Federal Direct Loan Program, and Teacher Education Assistance for College and Higher Education Grant Program, 82 Fed. Reg. 27621 (June 16, 2017) (to be codified at 34 C.F.R. pts. 668, 674, 682, and 685). 
action waivers, following the pattern of the Trump administration's across-theboard reversals on this issue. ${ }^{67}$

Another example of a regulatory shift will likely come from the Department of Labor ("DOL"), which in April 2016 passed a game-changing series of rules and exemptions to eliminate costly conflicts of interest in rendering retirement investment advice ${ }^{68}$ The new fiduciary rule (requiring that professionals provide retirement financial advice in the best interests of their clients) became applicable on June 9,2017. The application of the remaining regulations, which allows for mandatory arbitration, but bans class-action waivers, was delayed until January 1, $2018 .^{69}$ The new DOL director appointed by President Trump has announced that it is considering changing or eliminating some or all

${ }^{67}$ The notice postponing the implementation of the 2016 final rules laid the groundwork for reversal, as the DOE expressed concerns about the costs of implementing the rule in colleges, and also noting that the plaintiffs in the underlying litigation "raised serious questions concerning the validity of certain provisions of the final regulations...." Id. The DOE announced that it would continue its review and revisions to the 2016 regulations. Id. at 27622.

${ }^{68}$ See Definition of the Term "Fiduciary"; Conflict of Interest Rule-Retirement Investment Advice, 81 Fed. Reg. 20946-47 (Apr. 8, 2016). Financial professionals providing retirement investment advice to retail investors must put their clients' best interests above their own financial interest, charge only reasonable compensation, and not make any material misleading statements. Id. at 20991. See also Benjamin P. Edwards, Conflicts \& Capital Allocation, 78 OHIO ST. L.J. 181, 225 n.275 (2017) (noting that in a changing political climate Congress may block or overturn DOL's fiduciary rule) (citations omitted).

69 The fiduciary rule and related regulatory exemptions became effective on April 10, 2016, but the DOL delayed implementation of the fiduciary rule and other regulations for twelve months, and remaining regulations for eighteen months. Definition of the Term "Fiduciary"; Conflict of Interest Rule-Retirement Investment Advice; Best Interest Contract Exemption; Class Exemption for Principal Transactions in Certain Assets Between Investment Advice Fiduciaries and Employee Benefit Plans and IRAS; Prohibited Transaction Exemptions, 82 Fed. Reg. 16902 (Apr. 7, 2017); Mark Schoeff Jr., OMB Approves Proposal for 18-month Delay of DOL Fiduciary Rule's Second Phase, INV. News (Aug. 29, 2017, 1:52 PM), http:/www.investmentnews.com/article/20170829/FREE/170829929/omb-approves-

proposal-for-18-month-delay-of-dol-fiduciary-rules [https://perma.cc/8B7X-XUFE]. However, on February 3, 2017, President Trump signed an Executive Memorandum directing the DOL to review the fiduciary rule, published in the federal register. Fiduciary Duty RuleMemorandum for the Secretary of Labor, 82 Fed. Reg. 9675 (Feb. 7, 2017). Thereafter, the DOL delayed application of the fiduciary rule until June 9, 2017, but further delayed some of the other rules until January 1, 2018. See Definition of the Term "Fiduciary"; Conflict of Interest Rule-Retirement Investment Advice; Best Interest Contract Exemption; Class Exemption for Principal Transactions in Certain Assets Between Investment Advice Fiduciaries and Employee Benefit Plans and IRAS; Prohibited Transaction Exemptions, 82 Fed. Reg. 12319,12325 (proposed Mar. 2, 2017) (to be codified at 29 C.F.R. pt. 2510); 82 Fed. Reg., supra note 69, at 16902. On August 31, 2017 the DOL issued another proposed rule to further delay implementation of the other parts of the rule an additional eighteen months, to Ju1y 1, 2019. Extension of Transition Period and Delay of Applicability Dates; Best Interest Contract Exemption (PTE 2016-01); Class Exemption for Principal Transactions in Certain Assets Between Investment Advice Fiduciaries and Employee Benefit Plans and IRAS (PTE 2016-02); Prohibited Transaction Exemption 84-24 for Certain Transactions Involving Insurance Agents and Brokers, Pension Consultants, Insurance Companies, and Investment Company Principal Underwriters (PTE 84-24), 82 Fed. Reg. 41365 (proposed Aug. 31, 2017) (to be codified at 29 C.F.R. pt. 2510). 
parts of the rule. ${ }^{70}$ It is unlikely that the DOL's ban on the use of class-action waivers in agreements to provide retirement financial advice will survive. Indeed, in defending the fiduciary rule and exemptions in pending litigation challenging the rules, the DOL stated that the department is changing its stance on the class-action waiver provision and would no longer defend it. ${ }^{71}$

Another abrupt reversal is in the context of three consolidated cases currently pending before the Supreme Court, ${ }^{72}$ challenging the National Labor Relations Board's ("NLRB") position that class-action waivers in employment agreements violate Section 7 of the National Labor Relations Act by precluding employees from engaging in "concerted activities for the purpose of collective bargaining or other mutual aid or protection." ${ }^{\prime \prime 3}$ The Court will resolve the conflict between the Seventh and Ninth Circuit, which have held that class-action waivers violate Section 7 of the NLRA ${ }^{74}$ and the Fifth Circuit's position that they do not. ${ }^{75}$ On June 16,2017 , the government took the nearly unprecedented

${ }^{70}$ Citing the February 3, 2017 Presidential Memorandum ordering the DOL to conduct an additional examination of the costs of the fiduciary rule and related exemptions, the DOL announced that during the transition phase it would be issuing a request for information to solicit additional comments on whether changes to the marketplace and firm structures warrant additional postponement of the remaining requirements of the DOL rule, or further changes to the rule (and related exemptions) itself. U.S. DEP'T OF LABOR, CONFLICT OF INTEREST FAQs (TRANSITION PERIOD), at 4 (May 2017).

${ }^{71}$ Carmen Germaine, DOL Drops Class Action Clause but Defends Fiduciary Rule, LAW360 (July 5, 2017, 5:34 P.M.), https://www.law360.com/articles/941168/dol-drops-class-actionclause-but-defends-fiduciary-rule [https://perma.cc/G5UA-7HAC]. In 2016, six separate lawsuits were filed by industry groups and associations against the DOL challenging various aspects of the new regulations, to include: Complaint at 2, Chamber of Commerce v. Perez, No. 16-CV-1476 (N.D. Tex. June 1, 2016) consolidated with Complaint at 2, American Council of Life Insurers v. Dep't of Labor, No. 16-CV-1530 (N.D. Tex. June 8, 2016) and Complaint at 13, Indexed Annuity Leadership Council v. Perez, No. 16-CV-01537 (N.D. Tex. June 8, 2016); Complaint at 1-2, Nat'l Ass'n for Fixed Anmuities v. Perez, No. 16-CV1035 (D.D.C. June 2, 2016), Complaint for Declaratory and Injunctive Relief at 1-2, Market Synergy Group, Inc. v. U.S. Dep't of Labor, No. 16-CV -4083 (D. Kan. June 8, 2016), and Complaint at 1-2, Thrivent Fin. for Lutherans v. Perez, No. 16-CV -3289 (D. Minn. Sept. 29, 2016). The district courts have rendered decisions in favor of the DOL and upheld the new regulations in all but the Thrivent Financial case, which is still pending. See Nat'1 Ass'n for Fixed Annuities v. Perez, 217 F. Supp. 3d 1, 6-7 (D.D.C. 2016); Chamber of Commerce v. Hugler, 231 F. Supp. 3d 152, 158-59 (N.D. Tex. 2017); and Mkt Synergy Grp, Inc. v. U.S. Dep't of Labor, 2017 U.S. Dist. LEXIS 23155, at*1-2 (D. Kan. 2017).

${ }^{72}$ Murphy Oil USA, Inc. v. N.L.R.B., 808 F.3d 1013 (5th Cir. 2015), cert. granted, 137 S. Ct. 809 (2017); Lewis v. Epic Sys. Corp., 823 F.3d 1147 (7th Cir. 2016), cert. granted, 137 S. Ct. 809 (2017); Morris v. Ernst \& Young, LLP, 834 F.3d 975 (9th Cir. 2016), cert. granted, 137 S. Ct. 809 (2017).

${ }^{73}$ D.R. Horton, Inc., 357 NLRB 184 (2012), rev'd in part, aff'd in part, D.R. Horton, Inc. v. N.L.R.B., 737 F.3d 344, 362 (5th Cir. 2013) (reversing NLRB's decision regarding classaction waivers, but affirming on other grounds).

${ }^{74}$ Lewis, 823 F.3d at1151; Morris, 834 F.3d at 979.

${ }^{75}$ Murphy Oil, 808 F.3d at1015. 
step of changing its position on this issue in its brief before the Supreme Court. $^{76}$

These examples illustrate the potential for targeted reform of mandatory arbitration, supported by the experience of agency staff, studies, and a public notice-and-comment process. But, the recent rollbacks and actions by the Trump administration are a stark reminder of the limits of regulatory reform.

\section{IMPROVING ACCESS AND FAIRNESS IN RESPONSE TO MANDATORY ARBITRATION: THE FINRA EXAMPLE}

Given the current legal landscape, an alternative, pragmatic approach to dealing with the vast expansion of mandatory arbitration is to focus on the arbitral forum itself. The leading example of this arbitral evolution is in the context of securities arbitration before FINRA, the self-regulatory organization responsible for oversight over broker-dealers in the United States. ${ }^{77}$ Because it is under direct regulatory oversight by the SEC, FINRA's processes and rules, including those governing securities arbitration, are subject to the SEC's investor-protection mandate. ${ }^{78}$ This is a significant distinction from arbitral forums where consumer, employment, and other commercial matters are resolved. ${ }^{79}$

Arbitration of disputes among securities industry participants has a long history, dating back to the founding of the predecessor self-regulatory organiza-

${ }^{76}$ Julia Manchester, Justice Department Flips Position in Supreme Court Case, THE HILL (June 17, 2017, 3:31 PM), http://thehill.com/homenews/administration/338274-justicedepartment-flips-from-obama-stance-to-oppose-nlrb-in-supreme [https://perma.cc/8FGM-6

M88]. The Solicitor General also authorized the NLRB to act on its own behalf. NAT'L

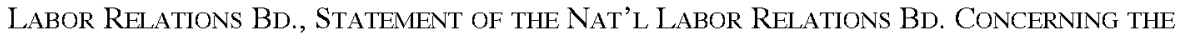
SuPREME COURT CASE OF NLRB V. MurPhy OIL USA, InC. (June 16, 2017), https:/www.nlrb.gov/news-outreach/news-story/statement-national-labor-relations-boardconcerning-supreme-court-case-nl-0 [https://perma.cc/5XXF-J8F2]. On August 9, 2017, the NLRB filed a brief in support of its prior position that such waivers violate Section 7 of the NLRA and are, therefore, unenforceable under the FAA's savings clause. Brief for the Petitioner at iii-iv, Nat'l Labor Relations Bd. v. Murphy Oil USA, Inc., No. 16-307 (Aug. 9, 2017).

77 The Exchange Act requires all broker-dealers that affect transactions in interstate commerce to register with the SEC. Securities Exchange Act of 1934 \&15(a)(1) (2012), 15 U.S.C. $\$ 780(a)(1)(2012)$. It further requires all broker-dealers to become members of an SRO (Securities Exchange Act $\S 15(\mathrm{~b})(8), 15$ U.S.C. $\S 78 o(\mathrm{~b})(8)$ ), and to abide by its rules and be subject to the SRO's regulatory processes and enforcement actions. Securities Exchange Act $\$ 19(\mathrm{~h})(1)(2012), 15$ U.S.C. $\$ 78 \mathrm{~s}(\mathrm{~h})(1)$ (2012). FINRA operates the largest forum for the resolution of securities disputes in the U.S. See Arbitration \& Mediation, FIN. INDUS. REG. AUTH., http:/www.finra.org/arbitration-and-mediation [https://perma.ce/79SFZVLV] (last visited Dec. 18, 2017). FINRA Dispute Resolution provides an arbitration forum for customer disputes and industry disputes, such as those between broker dealers and associated persons, or between two or more broker dealers.

78 15 U.S.C. \& $78 o-3(\mathrm{~b})(6)(2016)$

79 Barbara Black \& Jill I. Gross, Investor Protection Meets the Federal Arbitration Act, 1 Stan. J. COMPLEX LiTig. 1, 5-6 (2012). 
tions of the New York Stock Exchange ("NYSE") and NASD ${ }^{80}$ Customer claims were regularly arbitrated until the Supreme Court's decision in Wilko v. Swan ${ }^{81}$ where the Court held that claims under the Securities Act of 1933 were not subject to mandatory arbitration. ${ }^{82}$ For nearly thirty-five years, investors had a choice to bring their claims against brokers in either arbitration or go to court. ${ }^{83}$ The Court reversed course in Shearson/Am. Express, Inc. v. McMahon, where the Supreme Court held that securities disputes arising under the Securities Exchange Act of 1934 were arbitrable, ${ }^{84}$ and two years later expressly overruled Wilco v. Swan ${ }^{85}$ Today, the use of arbitration to resolve securities disputes among customers and members is nearly universal. ${ }^{86}$

When the Court considered McMahon in 1987, the SEC filed an amicus brief in support of arbitration of securities disputes, explaining that its newly granted authority over SROs under Congress's 1975 amendments to Section 19 of the Exchange $\mathrm{Act}^{87}$ could ensure the fairness and adequacy of SROs' arbitration procedures and enforce customers' rights under the Exchange Act. ${ }^{88}$ The SEC also helped develop a uniform code of arbitration procedure, which was voluntarily adopted by SROs. ${ }^{89}$ The SEC has since pushed SROs to develop a litigation model of arbitration consistent with procedural due process and designed to improve investors' perception of fairness. ${ }^{90}$

\footnotetext{
${ }^{80}$ See generally, Gross, supra note 2, at 174-76. Professor Gross explains that the considerations that drove the securities industry to prefer arbitration as a form of dispute resolution were to ensure that industry norms, rules, and practices would be enforced, ensure the good conduct of its members (which served to protect customers), and to provide a predictable and expedient resolution of disputes arising in a fast-moving market. $I d$. at 176-77.

81 Wilko v. Swan, 346 U.S. 427 (1953).

${ }^{82}$ Id. at 438.

83 Many courts also exercised supplemental jurisdiction over investors' state law claims. However, in Dean Witter Reynolds, Inc. v. Byrd, 470 U.S. 213 (1985), the Supreme Court held that the FAA required courts to compel arbitration of state law claims, even if it resulted in the inefficiency of bifurcated claims. Id. at 219-20.

${ }^{84}$ Shearson/Am. Express, Inc. v. McMahon, 482 U.S. 220,226 (1987).

${ }^{85}$ Rodriguez de Quijas v. Shearson/Am. Express, Inc., 490 U.S. 477, 485 (1989).

${ }^{86}$ After McMahon, the vast majority of broker-dealers in the country inserted PDAAs in their agreements with customers, requiring them to arbitrate any claims arising out of their brokerage relationship. See Barbara Black, Can Behavioral Economics Inform Our Understanding of Securities Arbitration?, 12 TENN. J. BUs. L. 107 (2011).

${ }^{87} 15$ U.S.C. \& 78o-3(b)(6) (2016) (SEC can only approve SRO rules that, among other things, are "designed to prevent fraudulent and manipulative acts and practices . . . and, in general, to protect investors and the public interest ...").

${ }_{88}$ Brief for the SEC as Amicus Curiae Supporting Petitioners, at 6-7, Shearson/Am. Express, Inc. v. McMahon, 482 U.S. 220 (1987) (No. 86-44), 1986 WL $727882 * 6-7$.

${ }^{89}$ Constantine N. Katsoris, Securities Arbitration After McMahon, 16 FoRDHAM URB. L.J. 361,363-64, 369 (1987).

${ }_{90}^{90}$ Teresa J. Verges, Opening the Floodgates of Small Customer Claims in FINRA Arbitration: FINRA v. Charles Schwab \& Co., Inc., 15 CARDOZO J. CONFLICT RESOL. 623, 630-31 (2014); Barbara Black, Is Securities Arbitration Fair to Investors?, 25 PACE L. REV. 1, 5-6 (2004).
} 
As early as 1989, the SEC approved amendments to SRO rules (now embodied in FINRA Rule 2268) ${ }^{91}$ requiring that specific language and disclosures be included in customer agreements that contain a PDAA, ${ }^{92}$ and further prohibiting SRO members from inserting "any condition" in a PDAA that limits or contradicts the arbitration rules of any SRO.$^{93}$ FINRA has effectively used Rule 2268(d) to prohibit member firms from inserting class-action waivers in customer agreements ${ }^{94}$ and, most recently, to address the recent trend of firms using forum selection clauses to change the hearing location or require arbitration in another forum. ${ }^{95}$

Between 1997 and 2007, the SEC approved nearly all of the rule proposals filed by the NASD as a result of a comprehensive review undertaken by the Arbitration Policy Task Force, which was appointed by the NASD's Board of Governors. ${ }^{96}$ The resulting 1996 Ruder Report contained over seventy recom-

91 See Order Approving Proposed Rule Changes by NYSE, NASD, and American Stock Exchange Relating to the Arbitration Process and the Use of Predispute Arbitration Clauses, 54 Fed. Reg. 21144 (May 10, 1989). NASD members were informed in an August 1989 Notice to Members ("NTM") that the amendments included an express prohibition on the use of language that "limits" or "contradicts" an SRO's arbitration rules. Nat'l Ass'n of Sec. Dealers, Inc., NTM Number 89-58 (Aug. 1989).

${ }^{92}$ FINRA Rule 2268(a) requires that any PDAA be highlighted and be preceded by language expressly set out in the rule that alerts customers to the fact that the agreement contains a PDAA and the consequences of entering into an arbitration agreement. FINRA Rule 2268(a) (2011).

${ }_{93} I d$. at $2268(\mathrm{~d})(1)$.

94 Although the rule does not expressly address judicial class actions, it prohibits members from including in their PDAAs "any condition that ... limits the ability of a party to file any claim in court permitted to be filed in court under the rules of the forums in which a claim may be filed under the agreement." Id. at 2268(d)(3). FINRA's Board of Governors has made clear that when Rule 2268(d)(3) is read together with FINRA Rule 12204(d)-which proscribes class actions in arbitration-judicial class actions are permitted and any provision to limit a customer's ability to bring or participate in a class action would be invalid. See Decision at 3, Dep't of Enforcement v. Charles Schwab, Compl. No. 2011029760201 (Apr. 24, 2014); see also Verges, supra note 90, at 635.

95 See Fin. Indus. Reg. Auth., Regulatory Notice 16-25, Forum SElection Provisions Involving Customers, Associated PERsons AND MEMBER FiRMS at 5 (July 2016), where FINRA recently reminded its members that Rule 12200 under the Customer Code preserves a customer's right to demand arbitration, regardless of whether the firm has a PDAA with its customer, and that the firm is prohibited by Rule 2268 from including any provision in its customer agreement that abrogates that right.

96 NAT'l Ass'n of SEC. DEALERS, InC., SeCurities ARBitration ReForm: RePort of the ARBITRATION POLICY TASK FORCE at 1 (Jan. 1996). The resulting 1996 Report of the Arbitration Task Force, known as the "Ruder Report" (named after head of the task force, former SEC Chairman Robert S. Ruder), proposed a number of reforms of the arbitration process. Although the Ruder Report did not propose a "radical overhaul" of the arbitration process, it did propose significant reforms and "greatly influenced the future direction of securities arbitration." JERRY W. MARKhaM \& Rigers GJYShI, Research HaNdBoOK ON SECURities REGULATION IN THE UNITED STATES 425 (2014). 
mendations to "revamp securities industry arbitration," most of which have been implemented in some form. ${ }^{97}$

The SEC has since approved new FINRA rules or amendments designed to improve investors' access to the forum, provide certain due process protections, level the playing field, and increase transparency. ${ }^{98}$ FINRA has amended the definition of "public arbitrator" to eliminate individuals with ties to the securities industry from the public arbitration pool, ${ }^{99}$ and provide customers with the option of an "all public" arbitration panel. ${ }^{100}$ FINRA's rules assure that customers can proceed at a geographic hearing location that is convenient for them. ${ }^{101}$ FINRA has also amended its procedural rules to significantly limit the grounds upon which motions to dismiss may be granted prior to a hearing, thereby assuring that most customer claims be reviewed on the merits. ${ }^{102}$ It has also simplified the discovery process through a presumptive automatic exchange of

${ }^{97}$ NASD Dispute Resolution, The Arbitration Policy Task Force Report-A Report Card 1, 5 (July 27, 2007).

${ }_{98}$ Verges, supra note 90 , at 635; Black, supra note 90, at 5-6.

99 Fin. Indus. Reg. Auth., Regulatory Notice 08-22, Definition of Public Arbitrator, SEC Approves Rule Change to AMEND the DeFinition of Public ARBitrator in the ARBITRATION CODES FOR CUSTOMER AND INDUSTRY DISPUTES 3 (2008), http://www.finra.org/web/groups/industry/@ip/@reg/@notice/documents/notices/p038472.p df [https://perma.cc/J5XR-5R6D] (announcing amendments to the definition of public arbitrator in the Customer Code (Rule 12100(u))) and corresponding Industry Code (Rule 13100(u)); see also Fin. Indus. Reg. Auth., Regulatory Notice 13-21, Public ARbitrator DeFinition, SEC APPROVEs AmENDMENTS to ARBITRATION CODES TO REVISE THE DEFINITION OF PUBLIC ARBITRATOR (2013), http://www.finra.org/web/groups/industry/

$@$ ip/@ reg/@notice/documents/notices/p272613.pdf [https://perma.cc/N5RH-HL3M] (amending FINRA Rules 12100(u) (Customer Code) and 13100(u) (Industry Code) to exclude persons associated with a mutual fund or hedge fund from serving as a public arbitrator).

${ }^{100}$ Fin. Indus. Reg. Auth., Regulatory Notice 11-05, Arbitration Panel Composition, Customer Option to Choose an All Public Arbitration Panel in All Cases 3-4 (2011),

http://www.finra.org/web/groups/industry/@ip/@reg/@notice/documents/notices/p122879.p df [https://perma.cc/PFD5-KBZU] (announcing new Rule 12402 and Rule 12403 (consolidating former FINRA rules on arbitrator panel composition and selection) that provide customers with the option of selecting an "all public" panel in cases requiring three-arbitrator panels (claims over $\$ 100,000)$ ).

101 Fin. Indus. Reg. Auth., Regulatory Notice 10-17, Hearing Locations, AMENDMENTS TO THE ARBITRATION Rules ON HEARING Locations 2 (2010), http://www.finra.org/web/groups/industry/@ip/@reg/@notice/documents/notices/p121222.p df [https://perma.cc/PM6X-U9S9] (amending FINRA Rule 12213 (Customer Code) to provide a customer with the option to request hearing location closest to his or her residence).

102 Fin. Indus. Reg. Auth., Regulatory Notice 09-07, Motion to Dismiss AND ELIGIBILITY RULES, SEC APPROVES NEW MOTION TO DISMISS RULE AND AMENDMENT TO THE ELIGIBILITY RULE IN ARBITRATION; FINRA IMPOSES IMMEDIATE 30-DAY MORATORIUM ON MOTIONS TO DisMiss 1,3 (2009), http:/www.finra.org/web/groups/industry/@ip/@ reg/ @ notice/documents/notices/p117757.pdf [https:/perma.cc/3677-G2FU] (adopting new FINRA Rules 12504 (Customer Code) and 13504 (Industry Code), that govern motions to dismiss in arbitration, and amending existing 12206 (Customer Code) and 13206 (Industry Code), which set forth jurisdictional eligibility requirements for arbitration). 
documents on customer and industry lists of documents set forth in FINRA's Discovery Guide. ${ }^{103}$ FINRA has also attempted to answer calls for more transparency by requiring arbitration panels to provide "explained decisions" upon the parties' request. ${ }^{104}$

Additionally, FINRA has reduced cost and improved access for investors with smaller claims. FINRA has a simplified arbitration process that allows for the case to proceed entirely on the pleadings and other papers submitted by the parties, and provides a hearing option solely at the request of the customer. ${ }^{105}$ FINRA recently increased the monetary limits for simplified arbitration proceedings from $\$ 25,000$ to $\$ 50,000 .^{106}$ For claims between $\$ 50,000$ and $\$ 100,000$, FINRA provides for single-arbitrator panels, which significantly reduces the cost of an arbitration hearing. ${ }^{107}$ Finally, in the wake of its most recent review of its arbitration forum, ${ }^{108}$ FINRA has announced it intends to file an amendment to its simplified process to provide investors with a third option - a telephonic hearing - in order to address investors' dissatisfaction with "paper cases."109

${ }^{103}$ Fin. Indus. Reg. Auth., Regulatory Notice 11-17, Arbitration, Revised Discovery Guide AND DOCument Production Lists for Customer Arbitration Procefdings 2 (2011), http://www.finra.org/web/groups/industry/@ip/@reg/@notice/documents/notices/ p123505.pdf [https://perma.ce/UX44-E8YN]. See FINRA Rule 12505 (2008); FINRA Rule 12506 (2017).

104 Fin. Indus. Reg. Auth., Regulatory Notice 09-16, Explainfd Arbitration DECISIONS, SEC APPROVES AMENDMENTS TO REQUIRE ARBITRATORS TO PROVIDE AN EXPLAINED DECISION AT PARTIES' JOINT REQUEST 1 (2009), http:/www.finra.org/web/

groups/industry/@ip/@reg/@notice/documents/notices/p1 18141.pdf [https://perma.cc/CE5Q -DHTE] (amending FINRA Rules 12214, 12514 and 12904 (Customer Code) and 13214, 13514 and 13904 (Industry Code)).

105 FINRA Rule 12800 (2017).

${ }^{106}$ Fin. Indus. Reg. Auth., Regulatory Notice 12-30, Simplified Arbitration, SEC APPROVES AMENDMENTS TO ARBITRATION CODES to RAISE THE Limit FOR Simplified ARBITRATION FROM \$25,000 TO \$50,000 1 (2012), http:/www.finra.org/webgroups/industry/ @ip/@reg/@notice/documents/notices/p127156.pdf [https://perma.cc/Z5ZL-K5UE] (amending FINRA Rule 12800 (Customer Code)).

${ }^{107}$ Fin. Indus. Reg. Auth., Regulatory Notice 09-13, Threshold For Single ARBitrator CASES, SEC APPROVES AMENDMENTS RAISING THE THRESHOLD FOR SingLE ARBITRATOR CASES TO $\$ 100,0001$ (2009), http:/www.finra.org/web/groups/industry/@ip/ $@ \mathrm{reg} / @$ notice/documents/notices/p1 18034.pdf [https://perma.cc/PX5A-Y7S7] (amending FINRA Rule 12401 (Customer Code) and Rule 13401 (Industry Code)). FINRA explained that the amendments would "streamline the dispute resolution process and decrease costs for users of the forum." $I d$. at 2.

${ }_{108}$ Nearly twenty years after the Ruder Report, FINRA appointed a thirteen-member Arbitration Task Force, chaired by Professor Barbara Black, "to consider possible enhancements to its arbitration forum to improve the transparency, impartiality and efficiency of FINRA's securities arbitration forum for all participants." News Release, FINRA, FINRA Announces Arbitration Task Force (July 17, 2014), https:/www.finra.org/newsroom/2014/finraannounces-arbitration-task-force [https://perma.cc/ZV94-EYAW].

109 The FINRA Dispute Resolution Task Force issued its Final Report and Recommendation on December 16, 2015; the final report observed that claimants who have their claims resolved exclusively on paper submissions are among the least satisfied of the forum's users, 
These changes over the last three decades have transformed the securities arbitration forum such that it compares favorably, if not significantly better, to arbitration forums for the resolution of consumer or other disputes. ${ }^{110}$ of course, concerns remain about the securities arbitration process, including the lack of transparency, ${ }^{111}$ arbitrator bias in favor of brokerage firms (who are repeat users of the forum), ${ }^{112}$ the increasing cost of arbitration (particularly with larger cases), ${ }^{113}$ and loss of judicial rulings on claims involving federal securities laws, regulations, and FINRA conduct rules. ${ }^{114}$ Yet, as the securities arbitration model has shown, pushing for reform to level the playing field for forced participants is a critical component of investor protection. ${ }^{115}$

Consumer and employee advocates should similarly push for changes to arbitration in the context of consumer, employment, and other non-traditional disputes. Given the expanding use of PDAAs, many with class-action waivers that are increasingly supported by Supreme Court jurisprudence, it is essential

and that they experienced the lowest win rates of 37 percent; the task force recommended an "intermediate approach," leaving the details to FINRA and the National Mediation and Arbitration Committee. FINRA DISPUTE RESOLUTION TASK FORCE, FINAL REPORT AND RECOMMENDATIONS OF THE FINRA DisPUTE RESOlution TASK FORCE 28-30 (2015), https:/www.finra.org/sites/default/files/Final-DR-task-force-report.pdf [https://perma.cc/ZFS2-4DGD].

110 Jill I. Gross, The End of Mandatory Securities Arbitration?, 30 PACE L. REV. 1174, 1186-89 (2010). Professor Gross further argues that the securities arbitration forum is not only fair to investors, but it also provides "a more hospitable forum than the court for the resolution of their disputes." Jill I. Gross, The Customer's Nonwaivable Right to Choose Arbitration in the Securities Industry, 10 BROOK. J. CORP. FIN. \& COM. L. 383, 398, 402-03 (2016) (tracing the history of securities arbitration and the customer's right to demand arbitration as a matter of investor protection and assurance of a dispute resolution forum for small claims).

111 See Benjamin P. Edwards, The Dark Side of Self-Regulation, 85 U. CIN. L. REV. 573 , 616-17 (explaining the need for increased transparency because "outside actors often struggle to bring pressure to bear on self-regulatory organizations because they cannot obtain information."); Benjamin P. Edwards, Arbitration's Dark Shadow, 18 Nev. L.J. 427, 431 (2018).

112 NASAA, supra note 5, at 2 (citing a recent empirical study confirming that individual investors have "negative views of arbitration" and believe "the system is biased against them"); see also Jill Gross \& Barbara Black, When Perception Changes Reality: An Empirical Study of Investors' Views of the Fairness of Securities Arbitration, 2008 J. DiSP. RESOL. 349,385 (2008) (in a 2008 survey of customers that had completed an arbitration, authors observed that a significant number of those surveyed believed the system was biased against them). These perceptions are not without empirical support. See Stephen J. Choi, et al., The Influence of Arbitrator Background and Representation on Arbitration Outcomes, 9 VA. L. \& BUS. REV. 43, 85 (2014) (empirical data supports arguments that panels with industry arbitrators result in lower outcomes for investors; also, the incentive for future selection impacts award amounts).

113 William B. L. Little, Fairness is in the Eyes of the Beholder, 60 BAYLOR L. REV. 73, 153 (2008).

114 Gilles, supra note 16, at 372, 409 (all forms of disputes are being "shunted into the hermetically-sealed vault of private arbitration, where there is no public, transparent decisionmaking process, much less stare decisis, or common law development").

115 Gross, supra note 2 at $183-84$. 
to make reforms to increase access, lower costs, and provide some due process protections for those claims.

\section{CONCLUSION}

The widespread use of mandatory arbitration provisions and class-action waivers have required domestic arbitral forums to evolve and incorporate due process protections and procedures to increase access, level the playing field, and provide transparency. Unless and until the misalignment of Supreme Court jurisprudence and the FAA is corrected through legislative action, there is little choice but to provide better protections for forced participants of the process, even if those protections may fall short of alleviating concerns about access, process, and fairness.

Businesses that use PDAAs should also encourage reforms in other arbitral forums, even if they come at the expense of some of the benefits of arbitration in the first place. Fundamental notions of fairness and access to justice require greater transparency and some of the procedural protections found in judicial proceedings, particularly when the disputes implicate, at least in part, matters of public policy. Political winds change course; an evolution to better access, fairness, transparency, and due process for forced users of arbitration in nontraditional claims may be the best defense to preserve it. 
[Vol. 18:437

[PAGE INTENTIONALLY LEFT BLANK] 